\title{
Three species of Echinococcus granulosus sensu lato infect camels on the Arabian Peninsula
}

\author{
Fahad A. Al-Hizab ${ }^{1} \cdot$ Nouh S. Mohamed ${ }^{2} \cdot$ Marion Wassermann $^{3} \cdot$ Mahmoud A. Hamouda $^{1} \cdot$ Abdelazim M. Ibrahim ${ }^{1}$. \\ Waleed R. El-Ghareeb ${ }^{4} \cdot$ Sherief M. Abdel-Raheem ${ }^{4} \cdot$ Thomas Romig $^{3} \cdot$ Rihab A. Omer $^{3,5}$ (D)
}

Received: 1 December 2020 / Accepted: 5 April 2021 / Published online: 17 April 2021

(C) The Author(s) 2021

\begin{abstract}
We report on the genetic identity of 36 Echinococcus cysts that were collected during a recent slaughterhouse survey of 810 locally bred camels (dromedaries) in the Eastern Province of the Kingdom of Saudi Arabia. Analysis of a partial nadl gene sequence showed that the majority $(n=29)$ belonged to E. granulosus sensu stricto, four to E. canadensis G6/7, and three to E. ortleppi. Eight of the 29 E. granulosus s.s. cysts contained protoscoleces; all other cysts were calcified and non-viable. This is the first report of the presence $E$. ortleppi from the Arabian Peninsula, a parasite that is typically transmitted via cattle. The results indicate widespread infection of camels with CE in eastern Saudi Arabia and an active role of camels in the lifecycles of at least E. granulosus s.s.. Complete coxl haplotype analysis of 21 E. granulosus s.s. isolates shows that the majority of variants circulating in eastern Saudi Arabia is distinct from but closely related to haplotypes from neighboring countries in the Middle East, which indicates the presence of this parasite in KSA for a longer period of time. All isolates of E. granulosus s.s. in this study belonged to the G1 cluster, although the G3 genotype has previously also been reported from the Middle East.
\end{abstract}

Keywords Echinococcus granulosus sensu stricto $\cdot$ E. ortleppi $\cdot$ E. canadensis G6/7 · Camels $\cdot$ Kingdom Saudi Arabia $\cdot$ Strains

\section{Introduction}

Cystic echinococcosis (CE) is a zoonosis caused by cestodes of the species complex Echinococcus granulosus sensu lato (s.l.). The adult tapeworms are asymptomatic intestinal parasites of dogs and wild carnivores which get infected by ingesting cystic

$\overline{\text { Fahad A. Al-Hizab and Nouh S. Mohamed contributed equally to this }}$ work.

Section Editor: Bruno Gottstein

Rihab A. Omer

rihab.omer@yahoo.com

1 Department of Pathology, College of Veterinary Medicine, King Faisal University, Hofof, Saudi Arabia

2 Department of Parasitology and Medical Entomology, Nile University, Khartoum, Sudan

3 Parasitology Unit 190p, Institute of Biology, University of Hohenheim, Emil-Wolff-Straße 34, 70599 Stuttgart, Germany

4 Department of Veterinary Public Health and Animal Husbandry (Meat Hygiene), College of Veterinary Medicine, King Faisal University, Hofof, Saudi Arabia

5 Department of Molecular Biology, Institute of Parasitology, University of Leipzig, Leipzig, Germany larval stages (metacestodes) that develop in herbivorous intermediate hosts (usually via offal after uncontrolled slaughter of livestock) (Eckert and Deplazes 2004; Moro et al. 2008). Cysts can grow in almost all organs of intermediate hosts, most often the liver and lungs, causing various degrees of morbidity and mortality depending on species of host and parasite, cyst size, and location. Apart from livestock (sheep, goats, cattle, camels, donkeys) and wild herbivores, humans can acquire CE by accidental ingestion of Echinococcus eggs from the environment (Eckert and Deplazes 2004).

To date, five species of Echinococcus are known to cause $\mathrm{CE}$ in animals or humans. Echinococcus granulosus sensu stricto (s.s.) is most frequently transmitted in a lifecycle involving domestic dogs and sheep, although a range of other mammals (including camels) are also suitable intermediate hosts; this parasite is responsible for the majority of human cases worldwide (Alvarez Rojas et al. 2014). Echinococcus equinus is adapted to equids (horses and donkeys) as intermediate hosts, E. ortleppi to cattle, and E. canadensis consists of genotypes that frequently infect camels, pigs, and wild herbivores. The fifth species, E. felidis, is a wildlife parasite of subSaharan Africa that may not be zoonotic. All these taxa show marked differences in host range and pathogenicity (also to humans), but are difficult to differentiate morphologically, 
particularly in the cyst stage. Molecular characterization of the causative agents of $\mathrm{CE}$ is therefore mandatory to gather information on transmission patterns and control options (Alvarez Rojas et al. 2014).

Few such data on CE are available from the Kingdom of Saudi Arabia (KSA), although the presence and frequency in humans and livestock are well documented. Substantial numbers of human CE cases were reported from KSA (Fahim and Al Salamah 2007; Al-Malki and Degheidy 2013), as well as from neighboring Yemen, Oman, and Qatar (Deplazes et al. 2017). In livestock, prevalences reported from KSA are 0.5$34.6 \%$ in camels, $0.0-28.7 \%$ in cattle, $0.1-69.6 \%$ in sheep, and $0.5-19.8 \%$ in goats. Most studies were done in the western and central parts of the country, except one study each on camels and sheep in Eastern Province (Farah 1987; Haroun et al. 2008; Ibrahim 2010; Toulah et al. 2012; Al-Malki and Degheidy 2013; Hayajneh et al. 2014; Almalki et al. 2017; ElGhareeb et al. 2017; Toulah et al. 2017; Abdel-Baki et al. 2018; Fdaladdin et al. 2018; Al-Hizab et al. 2018).

The KSA is a major importer of livestock for slaughter and consumption from other Middle Eastern and African countries. Prevalence figures from slaughterhouse survey often do not discriminate between locally raised and imported animals. However, prevalence differences may be substantial: Al-Malki and Degheidy (2013) found CE in $9.6 \%$ of local, but $29.2 \%$ of imported sheep, while Fdaladdin et al. (2018) and El-Ghareeb et al. (2017) found local sheep slightly more frequently infected than imported sheep in Al-Madina and Al-Ahsa, respectively.

The molecular identification of the causative Echinococcus species in KSA is limited to two studies: Metwally et al. (2018) identified only E. granulosus s.s. among 18 fertile cysts from sheep and camels from Riyadh, and Al-Mutairi et al. (2020) identified one cyst each from sheep and camel from western KSA as E. granulosus s.s.. In neighboring Oman, E. granulosus s.s. was found in camels, cattle, sheep, and goats, and E. canadensis G6/7 in camels and cattle (AlKitani et al. 2015; Al-Kitani et al. 2020). One isolate from a human patient in Yemen was identified as E. granulosus s.s. (Alam-Eldin et al. 2015).

Here, we provide first insights into the causative agents of CE circulating in local camel breeds in the eastern parts of KSA. It is intended as a baseline study, to be followed by more comprehensive surveys of other livestock species in this vast and under-researched region.

\section{Material and methods}

\section{Study area and origin of samples}

The Eastern Province (asch-Sharqiyya), bordering Iraq, Kuwait, Qatar, UAE and Oman, is the largest province of the Kingdom of Saudi Arabia in terms of area and the third in terms of human population. More than half of the 673,000 $\mathrm{km}^{2}$ area is covered by the uninhabitable Rub'al Khali desert. No precise numbers of livestock are available for the province, but camels, sheep, and goats are the principle species kept.

The samples used in this study had been collected in the course of a survey by Al-Hizab et al. (2018), who found Echinococcus cysts in the livers of 216 out of 810 dromedaries (Camelus dromedarius) of different local breeds slaughtered for meat in the abattoirs of Al Omran, Al Ahsa, and Al Dammam; one cyst per camel was isolated for further investigation, while cysts in locations other than the liver were not recorded and collected. Age and sex of the examined animals were documented, as well as cyst size and fertility status. Metacestode tissue and cyst fluid were transferred into sterile tubes with 70\% EtOH. Protoscoleces were detected in eight cysts. These, and further 59 randomly selected non-fertile cysts, each from different camels, were provided for molecular identification of the causative Echinococcus species.

\section{DNA preparation}

DNA was prepared using the $0.02 \mathrm{M} \mathrm{NaOH}$ method as described previously (Hüttner et al. 2008). Briefly, cyst fluid was centrifuged and examined microscopically, and one protoscolex or a tissue piece of similar size was transferred in a volume of $1 \mu \mathrm{l}$ cyst fluid via pipette to $10 \mu \mathrm{l}$ of $0.02 \mathrm{M}$ $\mathrm{NaOH}$ solution and heated up to $95{ }^{\circ} \mathrm{C}$ for $15 \mathrm{~min}$. The resulting lysate was used directly as DNA template for the PCR.

\section{Polymerase chain reaction of partial nad 1 gene for species differentiation}

For species identification, a 189 bp long fragment of the nadl gene was analyzed. The amplification was carried out using the forward and reverse primers $5^{\prime}$ TGT TTT TGA GAT CAG TTC GGT GTG ' 3 and 5' CAT AAT CAA ACG GAG TAC GAT TAG '3, respectively. If necessary, a second/nested PCR was performed using the forward primer $5^{\prime}$ CAG TTC GGT GTG CTT TTG GGT CTG ' 3 and the reverse primer 5' GAG TAC GAT TAG TCT CAC ACA GCA '3 (Hüttner et al. 2008). PCR reaction mixture was in total of $25 \mu$ containing 10 pmol of either the first PCR or nested PCR primers, $10 \mathrm{mM}$ Tris- $\mathrm{HCl}(\mathrm{pH} 8.3), 50 \mathrm{mM} \mathrm{KCl}, 2 \mathrm{mM} \mathrm{MgCl} 2,200 \mu \mathrm{M}$ of each dNTP, $0.125 \mathrm{U}$ Ampli-Taq polymerase (Applied Biosystems), and $2 \mu \mathrm{l}$ of the lysate in the first PCR or $2 \mu \mathrm{l}$ first-PCR-product as a template for the second PCR. PCR amplification conditions were identical for both PCRs as follows: an initial denaturation step at $95^{\circ} \mathrm{C}$ for 5 min followed by 35 cycles of denaturation at $95^{\circ} \mathrm{C}$ for $30 \mathrm{~s}$, annealing at 55 ${ }^{\circ} \mathrm{C}$ for $30 \mathrm{~s}$, and extension at $72{ }^{\circ} \mathrm{C}$ for $30 \mathrm{~s}$. After a final extension step at $72{ }^{\circ} \mathrm{C}$ for $5 \mathrm{~min}$, the PCR products were cooled down to $4{ }^{\circ} \mathrm{C}$. 


\section{Polymerase chain reaction of the cox 1 gene}

For further phylogenetic and haplotype analyses of the E. granulosus s.s. samples, the complete coxl gene was amplified and sequenced. PCR was performed using primers described previously (Hüttner et al. 2008). In brief, for the first PCR a $25 \mu \mathrm{l}$ reaction containing $10 \mathrm{pmol}$ of the forward and the reverse outer primers (coxl outer forward primer: 5' TTA CTG CTA ATA ATT TTG TGT CAT ' 3 and coxl outer reverse primer: $5^{\prime}$ GCA TGA TGC AAA AGG CAA ATA AAC '3), $10 \mathrm{mM}$ Tris- $\mathrm{HCl}$ ( $\mathrm{pH} 8.3$ ), $50 \mathrm{mM} \mathrm{KCl}, 2 \mathrm{mM}$ $\mathrm{MgCl}_{2}, 200 \mu \mathrm{M}$ of each dNTP, $0.125 \mathrm{U}$ Ampli-Taq polymerase (Applied Biosystems), and $2 \mu \mathrm{l}$ of the lysate. The amplicons produced by the first primers were used as DNA templates for the nested PCR using the nested primer pair (coxl nested forward primer: 5' GTT AGT TTT GAC TGT ACG TTT TCA ' 3 and coxl nested reverse primer: 5' GAC TAA TAA TCA ACT TAG ACT TAC '3). Reaction mixture was set up to $50 \mu \mathrm{l}$ using $20 \mathrm{pmol}$ of each nested primer, $10 \mathrm{mM}$ Tris- $\mathrm{HCl}(\mathrm{pH} 8.3), 50 \mathrm{mM} \mathrm{KCl}, 2 \mathrm{mM} \mathrm{MgCl} 2$, $200 \mu \mathrm{M}$ of each dNTP, $0.25 \mathrm{U}$ Taq polymerase, and $2 \mu \mathrm{l}$ of the PCR amplicons. Conditions of amplifications were identical for both PCRs. PCR conditions were as follows: an initial denaturation step at $95^{\circ} \mathrm{C}$ for $5 \mathrm{~min}$ followed by 35 cycles of denaturation at $95^{\circ} \mathrm{C}$ for $30 \mathrm{~s}$, annealing at $55^{\circ} \mathrm{C}$ for $30 \mathrm{~s}$, and extension at $72{ }^{\circ} \mathrm{C}$ for $2 \mathrm{~min}$. After a final extension step at 72 ${ }^{\circ} \mathrm{C}$ for $5 \mathrm{~min}$, the PCR products were cooled down to $4^{\circ} \mathrm{C}$.

\section{PCR product visualization and sequencing}

PCR products were visualized using $1.5 \%$ agarose gel (GENAXXON) stained with GelRed (Biotum). Five microliter of each PCR product were mixed with $1 \mu \mathrm{l} 6 \times$ DNA loading dye (Thermo scientific) and loaded on the gel. Electrophoresis was carried out at $5 \mathrm{~V} / \mathrm{cm}$ for $20 \mathrm{~min}$. PCR products were viewed under UV light transilluminator (INTAS). The obtained amplicons were purified using the High Pure PCR Product Purification Kit (Roche) following the manufacturers instruction. PCR amplicons' lengths were compared against a middle range DNA ladder (Thermo scientific).

PCR amplicons were sequenced by GATC-biotech company (Germany).

\section{Genetic diversity analysis}

Echinococcus species identification of amplified nad1 gene was done by comparison with available sequences in the NCBI GenBank database using the BLAST nucleotide algorithm (http://www.ncbi.nlm.nih.gov/Blast.cgi).

Obtained chromatograms of the E. granulosus s.s. coxl sequences were viewed and manually edited using GENtle v. 1.9 [University of Cologne, Germany (Manske 2006)] and aligned by MEGA7 (Kumar et al. 2016). Indices of population diversity such as the number of haplotypes $(\mathrm{H})$, segregating sites (S), haplotypes diversity (Hd) and the average number of nucleotide differences between two sequences (p); Tajima's D test, Fu and Li's D* and F* statistics analysis were obtained using DnaSP v5.10 to estimate the neutral theory of natural selection. For the construction of the phylogenetic tree and haplotype analysis, the complete coxl sequences of previously published E. granulosus s.s. sequences from different geographic regions are used as reference sequences (Table 1). The sequences were selected based on their origin, focusing on isolates from countries in the Middle East known to export livestock to Saudi Arabia. In addition to these, sequences were included that most closely matched the haplotypes found in the present study after BLAST search. The construction of the phylogenetic tree was based on the maximum likelihood method. The model with the lowest BIC scores (Bayesian information criterion) was considered the best model to describe the nucleotides substitution patterns. Tamura-Nei's model was used for constructing the phylogenetic tree with 1000 bootstraps using MEGA7 software. Taenia solium was used as outgroup taxon [AB066493.1; (Nakao et al. 2002)]. The parsimony haplotype networks were calculated using the online TCS software v 1.8 (Clemet et al. 2000) and tcsBU (Múrias dos Santos et al. 2016).

\section{Results}

\section{Species identification of Echinococcus spp.}

Species differentiation using a small fragment of the nadl gene was successful with 36 out of 67 cysts. Echinococcus granulosus s.s. was dominant among the analyzed samples (29/36), followed by E. canadensis (4/36) and E. ortleppi (3 /36). All cysts were located in the liver (other organs were not examined) and measured less than $4 \mathrm{~cm}$ in diameter. Data on fertility status of the cysts as well as age and sex of the camels are presented in Table 2 .

\section{Genetic diversity and phylogenetic analyses}

The complete cox 1 gene could be successfully amplified from 21 out of the 29 E. granulosus s.s. isolates. Nine different haplotypes were found, six of which had not been described before. Sequences were deposited in GenBank under the accession numbers MW051119- MW051127.

Comparison with GenBank entries revealed that KSA haplotypes were most closely related with sequences found in western Asia including the Middle East (Table 3). The haplotype H06 from our panel is identical with the most common genetic variant of E. granulosus s.s. which can be found worldwide. 
Table 1 Origin and accession numbers of $\operatorname{cox} 1$ sequences used for phylogenetic analyses

\begin{tabular}{|c|c|c|c|c|c|}
\hline Region & Accession no. & Reference & Region & Accession no. & Reference \\
\hline \multirow{7}{*}{$\begin{array}{l}\text { North Africa } \\
\text { Tunisia }\end{array}$} & & & \multicolumn{2}{|l|}{ Western Asia } & \\
\hline & MG672267 & (Kinkar et al. 2018a) & Jordan & AB688594 & (Yanagida et al. 2012) \\
\hline & MG672268 & & & AB688599 & \\
\hline & MG672269 & & & AB688601 & \\
\hline & MG672271 & & Iran & JQ250807 & \\
\hline & MG672273 & & & JQ250810 & \\
\hline & MG672276 & & & JQ250813 & \\
\hline \multirow[t]{5}{*}{ Algeria } & MG808312 & (Laatamna et al. 2019) & & MG682537 & (Kinkar et al. 2018b) \\
\hline & MG808345 & & & MG682538 & \\
\hline & MG808346 & & & MG682539 & \\
\hline & MG808348 & & & MG682540 & \\
\hline & & & & MG682541 & \\
\hline \multicolumn{2}{|l|}{ South America } & & & MG672248 & (Kinkar et al. 2016) \\
\hline \multirow[t]{4}{*}{ Argentina } & KX039947 & (Laurimae et al., 2016) & & MG672244 & \\
\hline & MG672210 & (Kinkar et al. 2018a) & & MG672238 & \\
\hline & MG672214 & & & GQ856692 & (Nejad et al. 2012) \\
\hline & MG672258 & & & JQ219963 & $\begin{array}{l}\text { Mohammadzadeh et al., } \\
\text { Unpublished }\end{array}$ \\
\hline \multirow[t]{3}{*}{ Brazil } & MG672224 & & Turkey & KU925378 & (Kinkar et al. 2016) \\
\hline & MG672226 & & & KU925404 & \\
\hline & MG672229 & & & KU925358 & \\
\hline Peru & AB688620 & (Yanagida et al. 2012) & & MG682530 & (Kinkar et al. 2018b) \\
\hline Europe & & & & MG682531 & \\
\hline France & MG682520 & (Kinkar et al. 2018b) & & MG682534 & \\
\hline \multirow{4}{*}{ Italy } & MG682522 & & & MG682536 & \\
\hline & MG672278 & (Kinkar et al. 2018a) & Armenia & KX020342 & Ebi et al., unpublished \\
\hline & MG672133 & & & KX020377 & \\
\hline & MG672281 & & & KX020403 & \\
\hline Finland & MG672132 & & Far East Asia & & \\
\hline \multirow[t]{2}{*}{ Moldova } & MG672145 & & Russia & AB777905 & (Konyaev et al. 2013) \\
\hline & MG672146 & & & AB777906 & \\
\hline Romania & MG672131 & & & AB777907 & \\
\hline \multirow[t]{2}{*}{ Spain } & MG672137 & & & AB777908 & \\
\hline & KU925419 & (Kinkar et al. 2016) & China & AF297617 & (Le et al., 2002) \\
\hline \multirow{3}{*}{$\begin{array}{l}\text { South Asia } \\
\text { India }\end{array}$} & & & Australia & & \\
\hline & MG682542 & (Kinkar et al. 2018b) & Australia & NC044548 & (Kinkar et al. 2019) \\
\hline & MG682543 & & & KT968705 & (Alvarez Rojas et al. 2016) \\
\hline
\end{tabular}

Table 2 Age and sex of the camels and fertility status of the cysts that could be sequenced

\begin{tabular}{llll}
\hline Category & \multicolumn{3}{l}{} \\
\cline { 2 - 4 } & E. granulosus s.s. & E. ortleppi & E. canadensis \\
\hline Age of camel & & & \\
$<5$ years & 7 & 0 & 0 \\
5-10 years & 9 & 1 & 1 \\
$>$ 10 years & 13 & 2 & 3 \\
Sex of camels & & & \\
Male & 11 & 1 & 2 \\
Female & 18 & 2 & 2 \\
Cyst status & & & \\
Fertile & 8 & 0 & 0 \\
Sterile & 0 & 0 & 4 \\
Calcified & 21 & 3 & 4 \\
Total & 29 & 3 & \\
\hline
\end{tabular}

The nine haplotypes from Saudi Arabia differ within the coxl gene at nine positions. The exchanges or insertions with respect to the reference sequence AF297617 (Lee et al. 2002) are shown in Fig. 2. Seven of the sites are parsimonyinformative (Fig. 1).

A phylogenetic tree was constructed to investigate the relation of the 21 camel samples with 65 previously published sequences from different geographic regions. Four of the Saudi Arabian haplotypes, representing 12 isolates, cluster close together in the topmost clade; the other five haplotypes are dispersed over the tree (Fig. 2).

The resulting haplotype network shows two main clusters (Fig. 3): one centered on the most common globally distributed haplotype, which was represented by only two isolates in our sample set (H06). The second cluster, conforming to the genotypic G3 cluster, is formed by Asian and European haplotypes without any representatives from KSA. Five of the nine KSA haplotypes (representing 14 of 21 isolates) are closely related to each other and not known from other areas. 
Table 3 Similarity with deposited sequences in the GenBank database

\begin{tabular}{|c|c|c|c|}
\hline Haplotype & No. and names of KSA isolates & Similarity with closest sequences & Origin of closest sequences \\
\hline H01 & $\begin{array}{l}n=7 \\
(\mathrm{KSA}-1,3,5,12,13,14,16)\end{array}$ & $99.94 \%$ & Armenia, Jordan \\
\hline $\mathrm{H} 02$ & $\begin{array}{l}n=3 \\
(\mathrm{KSA}-17,19,20)\end{array}$ & $100 \%$ & Iran, Turkey, Russia \\
\hline H03 & $\begin{array}{l}n=2 \\
(\mathrm{KSA}-2,9)\end{array}$ & $99.88 \%$ & Iran, Moldova \\
\hline H04 & $\begin{array}{l}n=2 \\
\text { KSA-4, 6) }\end{array}$ & $99.81 \%$ & Algeria, Armenia, Jordan \\
\hline H05 & $\begin{array}{l}n=2 \\
(\mathrm{KSA}-11,15)\end{array}$ & $99.88 \%$ & Armenia, Jordan \\
\hline H06 & $\begin{array}{l}n=2 \\
(\mathrm{KSA}-18,21)\end{array}$ & $100 \%$ & global distribution \\
\hline $\mathrm{H} 07$ & $\begin{array}{l}n=1 \\
\text { (KSA-7) }\end{array}$ & $100 \%$ & Iran \\
\hline H08 & $\begin{array}{l}n=1 \\
(\mathrm{KSA}-8)\end{array}$ & $99.94 \%$ & Iran \\
\hline H09 & $\begin{array}{l}n=1 \\
(\text { KSA-10) }\end{array}$ & $99.88 \%$ & Algeria, Armenia, Jordan \\
\hline
\end{tabular}

The analysis of the neutrality indices showed high haplotype diversity $(\mathrm{Hd})$ of $0.790 \pm 0.00548$ with low nucleotide diversity (Pi) of 0.00145 , and the number of polymorphic (segregating) sites (S) detected was 8. The high $\mathrm{Hd}$, low $\mathrm{Pi}$, and the small number of $\mathrm{S}$ all indicate high diversity within the isolates. The average number of pairwise nucleotide differences $(k)$ was 2.324. Fu and Li's D* test statistic value was $0.19214(P>0.10)$; Fu and Li's $F^{*}$ test statistic value was $0.20851(P>0.10)$. Testing the natural selection theory resulted in a Tajima's D value of $0.14980(P>0.10)$. The calculated $\mathrm{Fu}$ and Li's $\mathrm{D}^{*}$ and $\mathrm{F}^{*}$ tests and Tajima's D test showing positively statistically insignificant values indicate that the population had undergone expansion.

\section{Discussion}

Only two previous studies had addressed the frequency of CE in the eastern region of Saudi Arabia: $26.7 \%$ of 810 locally raised camels were infected, based on a slaughterhouse survey in Al-Dammam, Al-Omran, and Al-Ahsa slaughterhouses (Al-Hizab et al. 2018); however, this is likely to be a gross underestimate as only livers were examined for $\mathrm{CE}$, and most cysts in camels appear to occur in the lungs (Omer et al. 2010; SHAHNAZI et al. 2011). In addition, 563 native sheep were examined in Al-Ahsa, of which $7.7 \%$ were infected (ElGhareeb et al. 2017). These figures range on a similar level as those from other regions of Saudi Arabia. Other countries on the Arabian Peninsula are data deficient, except for Oman where CE was found in all species of livestock albeit at low prevalence: a slaughterhouse survey conducted 2010-2013 found prevalences of $5.3 \%$ in camels, $0.6 \%$ in cattle, and < $1 \%$ in sheep and goats (Al-Kitani et al. 2015). From neighboring Kuwait, only older data exist, where CE was found in $39.6 \%$ of 293 slaughtered camels in the 1980s (Abdul-Salam and Farah 1988).

Based on molecular diagnosis, only E. granulosus s.s. had previously been found in KSA among 20 isolates from sheep and camels (Metwally et al. 2018; Al-Mutairi et al. 2020). The predominance of this species in KSA seems to be confirmed
Fig. 1 Sequence alignment of the 9 haplotypes. Substitutions were indicated with their nucleotide code, deletions were marked by ( - ), and dots ( . ) indicate identical nucleotide at the specified position in comparison with the reference sequence AF297617 (Lee et al. 2002). *nucleotides substitution positions, based on the start of the complete cox 1 gene, read vertically

\begin{tabular}{|c|c|c|c|c|c|c|c|c|c|c|}
\hline & & \multicolumn{9}{|c|}{ nucleotides substitution positions* } \\
\hline & & & & & & 1 & 1 & 1 & 1 & 1 \\
\hline & & 5 & 7 & 8 & 8 & 1 & 4 & 4 & 5 & 6 \\
\hline \multirow[t]{2}{*}{ haplotype } & $\mathrm{n}$ & 0 & 7 & 0 & 5 & 6 & 3 & 5 & 1 & 0 \\
\hline & & 5 & 5 & 0 & 5 & 5 & 1 & 8 & 1 & 1 \\
\hline AF297617.1 & & $\mathrm{C}$ & $\mathrm{T}$ & $\mathrm{C}$ & $\mathrm{T}$ & $\mathrm{A}$ & $\mathrm{T}$ & $\mathrm{G}$ & $\mathrm{A}$ & - \\
\hline $\mathrm{H} 01$ & 7 & . & . & $\mathrm{T}$ & $\mathrm{C}$ & G & . & A & . & $\mathrm{G}$ \\
\hline $\mathrm{HO} 2$ & 3 & . & . & $\mathrm{T}$ & C & . & . & . & $\mathrm{G}$ & G \\
\hline $\mathrm{H} 03$ & 2 & . & . & . & . & G & . & $A$ & . & G \\
\hline $\mathrm{H} 04$ & 2 & . & C & $\mathrm{T}$ & C & G & . & A & . & - \\
\hline $\mathrm{H} 05$ & 2 & . & . & $\mathrm{T}$ & C & G & . & $A$ & . & - \\
\hline H06 & 2 & . & . & . & C & . & . & . & . & G \\
\hline $\mathrm{H} 07$ & 1 & . & . & . & . & . & . & . & . & - \\
\hline $\mathrm{H} 08$ & 1 & $\mathrm{~T}$ & . & . & C & . & $A$ & . & . & G \\
\hline H09 & 1 & . & C & $\mathrm{T}$ & C & G & . & A & . & G \\
\hline
\end{tabular}




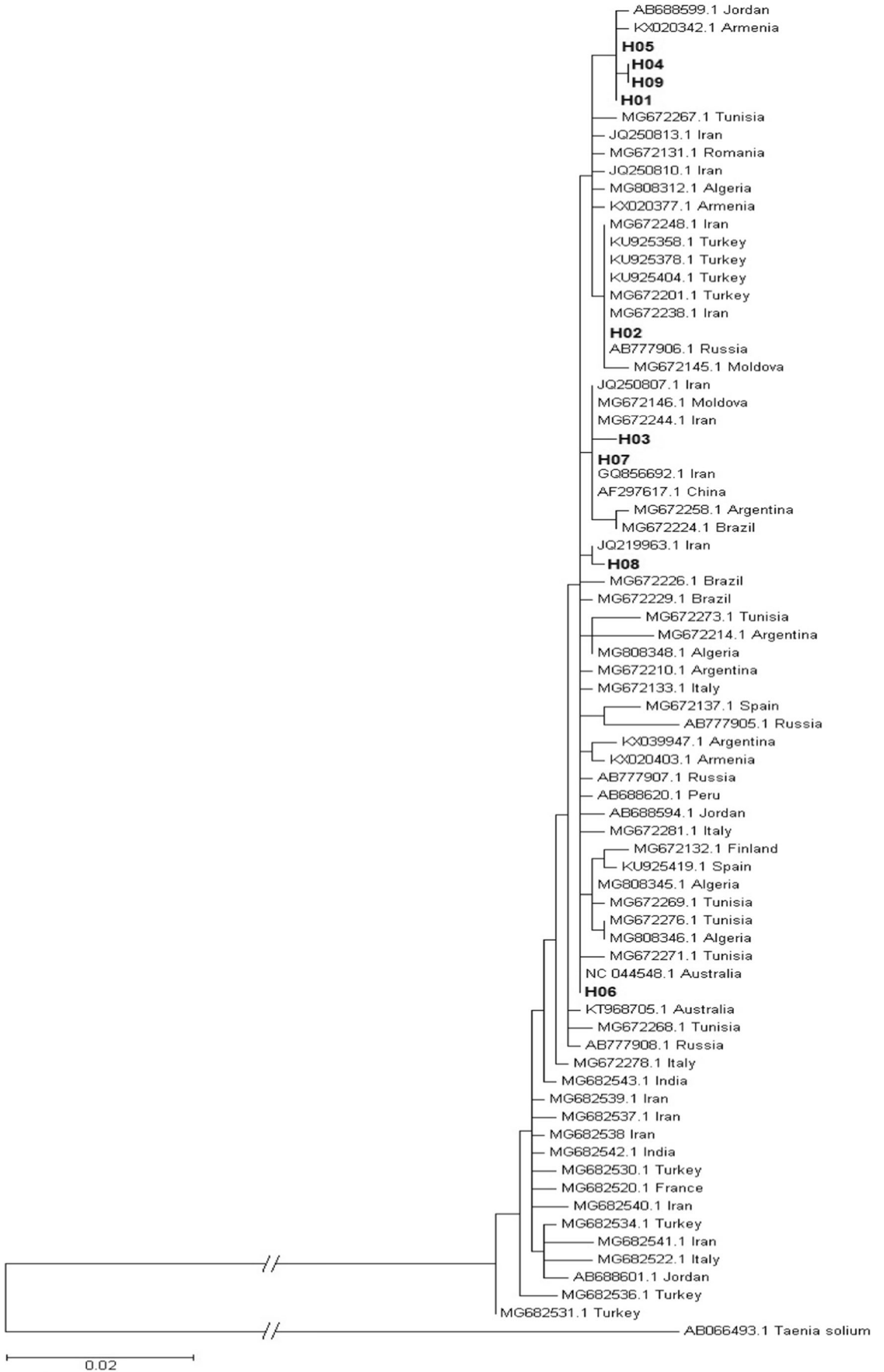


Fig. 2 Phylogenetic tree showing the relation between the Saudi Arabian haplotypes with 65 reference sequences. The Saudi Arabian haplotypes (H01-09) are in bold. The reference sequences along with their accession numbers and origin of isolate were included for each. T. solium was used as an outgroup taxon. The branch to outgroup was shortened by 0.2 substitutions per site

by our results, as the majority of cysts in our sample ( 29 of 36) belonged to E. granulosus s.s., only four and three to E. canadensis and E. ortleppi, respectively. However, this frequency distribution is unlikely to reflect the true situation, as E. canadensis and E. ortleppi are most often found in the lungs of their respective hosts (Omer et al. 2010; Banda et al. 2020), which were missed in this study as lung cysts had not been collected. Likewise, the fact that all cysts of $E$. canadensis and E. ortleppi were calcified in our sample is likely due to this sampling bias and does neither reflect the frequency of these parasite species nor the role of camels in their transmission. Camels are highly competent hosts for E. canadensis G6/7, formerly named the "camel strain", which is the most frequent Echinococcus taxon in camels worldwide (Bold et al. 2019; Dehghani et al. 2020; Anvari et al. 2021). In a major survey in Sudan, $74 \%$ of 2378 E. canadensis $\mathrm{G} 6 / 7$ cysts in camels were fertile (Omer et al. 2010). There are only four additional published records of camel infection with E. ortleppi, from Sudan, Egypt, and Iran, and in at least two of them, fertile cysts were described (Ahmed et al. 2013; Amer et al. 2015; Aziz and El Meghanawy 2016; Ebrahimipour et al. 2017); this parasite mainly affects cattle (Romig et al. 2017) but may use additional host species for transmission in certain areas (e.g., domestic pigs in Zambia (Banda et al. 2020)). Therefore, the role of camels in the lifecycle of E. ortleppi remains to be investigated.

All isolates for our studies were collected from local camel breeds, which means that three different species of E. granulosus s.l. circulate in the eastern region of KSA. Additional studies are needed to address the quantitative contribution of different species of livestock to their transmission. Very little data are available on the epidemiology of CE in the
Fig. 3 Parsimony haplotype network of the 21 camel isolates and 65 worldwide selected sequences. Haplotypes of each region are presented using color coding. White nodes represent hypothetical haplotypes. Sizes of colored nodes are proportional to the number of isolates found per haplotype. The cluster on the lower right side (without KSA isolates) is formed of sequences conforming to the G3 genotype

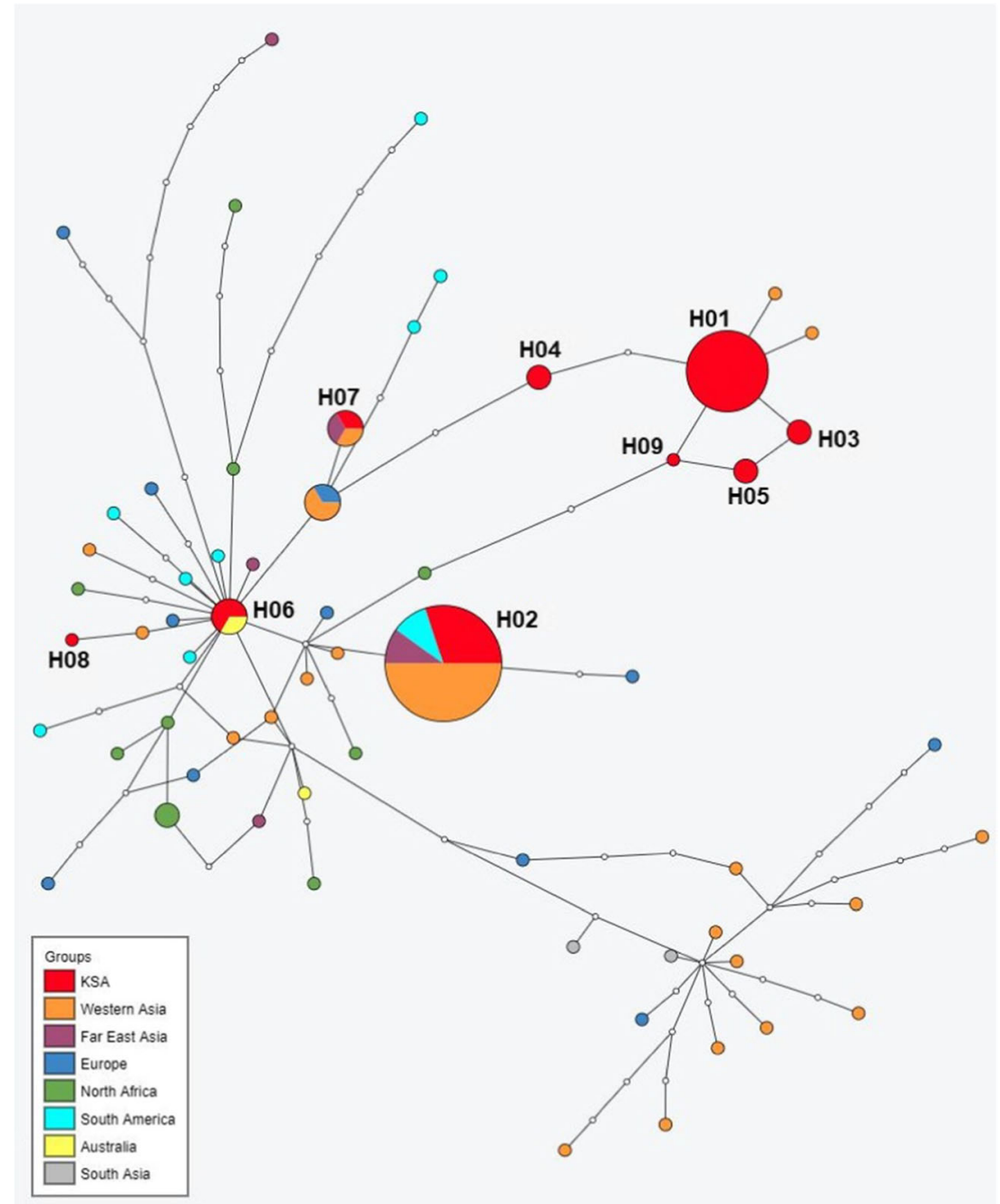


KSA apart from prevalence data from livestock; domestic dogs are highly likely to be the primary definitive hosts for all Echinococcus spp. in KSA, but the circumstances of transmission are unclear. Unsafe disposal of offal in slaughterhouses are major infection sources for dogs in many countries, but the economic standards of KSA have facilitated state-ofthe-art slaughtering facilities (Dar and Alkarmi 1997). There is only one older study that reported Echinococcus infection in dogs in KSA (15.6\% prevalence in Al-Ahsa region, Eastern Province) (Kawasmeh et al. 1984).

The Kingdom of Saudi Arabia is known for large-scale import of livestock from other Middle Eastern and African countries (e.g., Sudan). In most of these countries, CE is highly prevalent; therefore, the chance of importing infected animals is high. Some of the above cited slaughterhouse surveys for $\mathrm{CE}$ do not discriminate between local and foreign animals and those that do give no information on the origin of imported animals. It is therefore not surprising that in some studies, local breeds are more frequently infected than imported animals, and vice versa in other studies (Al-Malki and Degheidy 2013; Toulah et al. 2017; El-Ghareeb et al. 2017; Fdaladdin et al. 2018). In any case, it is of concern if such large-scale importation of parasites together with livestock results in "escapes" of these parasites into local circulation. This is particularly important in case of E. granulosus s.s., which is the causative organism of by far the largest proportion of human CE cases worldwide (Alvarez Rojas et al. 2014). We therefore compared the coxl haplotypes from our E. granulosus s.s. isolates with haplotypes available from other countries in the Middle Eastern region and worldwide. Interestingly, most haplotypes found in our panel (6 of 9) were unique and had not been reported from outside KSA but were most closely related with haplotypes that are known from Iran or Jordan. The three haplotypes that had been described before (H02, H06, and H07) are all known from the Middle Eastern region as well (Iran, Jordan, Turkey); it is noteworthy that H06, the most common and most widely distributed variant worldwide, is comparatively rare in our panel of samples. This genetic structure with their high "endemicity rate", high haplotype diversity, close relatedness (low nucleotide diversity), and the rarity of the ubiquitous H06 (with only two isolates) leads to the hypothesis that E. granulosus s.s. is of autochthonous presence at least in this part of the Arabian Peninsula and does not depend on importation. This hypothesis needs to be tested with a larger set of isolates, including samples from livestock species other than camels.

Further genetic analyses are also warranted concerning the origin of E. ortleppi and E. canadensis in KSA. Although infection of local camels in this study indicates local transmission, it cannot be excluded that these parasites had been introduced from elsewhere. As examples, E. ortleppi is highly prevalent in cattle in Brazil (Monteiro et al. 2016), and E. canadensis $\mathrm{G6} / 7$ is the predominant species in Sudan
(Omer et al. 2010), the two countries which account for the vast majority of imported livestock into KSA (WITS 2015).

In summary, CE of livestock in KSA is widespread, largely autochthonous at least for E. granulosus s.s.; camels are an important component of their lifecycles, but the precise background of transmission and possible origin of the parasites is in need of investigation.

Funding Open Access funding enabled and organized by Projekt DEAL. This work was financed by King Abdulaziz City for Science and Technology (KACST) through the grant number APR-35-169 and Alexander von Humboldt Foundation (AvH) through the grant number: 1127174GF.

Open Access This article is licensed under a Creative Commons Attribution 4.0 International License, which permits use, sharing, adaptation, distribution and reproduction in any medium or format, as long as you give appropriate credit to the original author(s) and the source, provide a link to the Creative Commons licence, and indicate if changes were made. The images or other third party material in this article are included in the article's Creative Commons licence, unless indicated otherwise in a credit line to the material. If material is not included in the article's Creative Commons licence and your intended use is not permitted by statutory regulation or exceeds the permitted use, you will need to obtain permission directly from the copyright holder. To view a copy of this licence, visit http://creativecommons.org/licenses/by/4.0/.

\section{References}

Abdel-Baki AAS, Almalki E, Al-Qqarishy S (2018) Prevalence and characterization of hydatidosis in Najdi sheep slaughtered in Riyadh city, Saudi Arabia. Saudi J Biol Sci 25:1375-1379

Abdul-Salam J, Farah M (1988) Hydatidosis in camels in Kuwait. Parasitol Res 74:267-270

Ahmed ME, Eltom KH, Musa NO, Ali IA, Elamin FM, Grobusch MP, Aradaib IE (2013) First report on circulation of Echinococcus ortleppi in the one humped camel (Camelus dromedaries), Sudan. BMC Vet Res 9:127

Alam-Eldin YH, Aaty HEA, Ahmed MA (2015) Molecular characterization of cystic echinococcosis: first record of G7 in Egypt and G1 in Yemen. Acta parasitol 60:662-665

Al-Hizab F, Hamouda M, Amer O, Edris A, El-Ghareeb W, AbdelRaheem S, Hawas N, Elmoslemany A, Ibrahim A (2018) Hepatic cystic echinococcosis in camels of Saudi Arabia: prevalence, risk factors and economic loss. J Camel Pract Res 25:295-302

Al-Kitani FA, Al Riyami S, Al Yahyai S, Hussain MH (2015) Abattoir based surveillance of cystic echinococcosis (CE) in the sultanate of Oman during 2010-2013. Vet Parasitol 211:208-215

Al-Kitani FA, Baqir S, Mansoor MK, Alriyami S, Hussain MH, Roberts D (2020) Genetic survey of cystic echinococcosis in farm animals in Oman. Trop Anim Health Prod 52:331-337

Al-Malki JS, Degheidy NS (2013) Epidemiological studies of hydatidosis among slaughtered sheep and human in Taif, Saudi Arabia. Assiut Vet Med J 59:45-50

Almalki E, Al-Quarishy S, Abdel-Baki AAS (2017) Assessment of prevalence of hydatidosis in slaughtered Sawakny sheep in Riyadh city, Saudi Arabia. Saudi J Biol Sci 24:1534-1537 
Al-Mutairi N, Taha H, Nigm A (2020) Molecular characterization of Echinococcus granulosus in livestock of Al-Madinah (Saudi Arabia). J Helminthol 94:e157

Alvarez Rojas C, Romig T, Lightowlers MW (2014) Echinococcus granulosus sensu lato genotypes infecting humans-review of current knowledge. Int J Parasitol 44:9-18

Alvarez Rojas CA, Ebi D, Gauci CG, Scheerlinck JP, Wassermann M, Jenkins DJ, Lightowlers MW, Romig T (2016) Microdiversity of Echinococcus granulosus sensu stricto in Australia. Parasitology 143:1026-1033

Amer S, Helal IB, Kamau E, Feng Y, Xiao L (2015) Molecular characterization of Echinococcus granulosus sensu lato from farm animals in Egypt. PLoS One 10:e0118509

Anvari D, Pourmalek N, Rezaei S, Fotovati A, Hosseini SA, Daryani A, Spotin A, Sarvi S, Hosseini M, Narouei MR, Kalkali M, Pendar F, Gholami S (2021) The global status and genetic characterization of hydatidosis in camels (Camelus dromedarius): a systematic literature review with meta-analysis based on published papers. Parasitology 148:259-273

Aziz ARA, El Meghanawy RA (2016) Molecular characterization of hydatid cyst from Egyptian one humped camels (Camelus dromedaries). PSM Vet Res 1:13-16

Banda F, Sikasunge C, Addy F, Wassermann M, Mackenstedt U, Kern P, Daugschies A, Mulinge E, Romig T (2020) Echinococcus ortleppi and Echinococcus canadensis G6/7 affect domestic animals in western Zambia. Acta Trop 211:105648

Bold B, Boué F, Schindler C, Badmaa B, Batbekh B, Argamjav B, Bayasgalan C, Ito A, Narankhuu U, Sagj A, Zinsstag J, Umhang $\mathrm{G}$ (2019) Evidence for camels (Camelus bactrianus) as the main intermediate host of Echinococcus granulosus sensu lato G6/G7 in Mongolia. Parasitol Res 118:2583-2590

Clemet M, Posada D, Crandall KA (2000) TCS: a computer program to estimate gene genealogies. Mol Ecol 9:1657-1659

Dar F, Alkarmi T (1997) Public health aspects of cystic echinococcosis in the Arab countries. Acta Trop 67:125-132

Dehghani M, Mohammadi MA, Hemmati S, Nasibi S, Rostami S, Fasihi Harandi M (2020) Cystic echinococcosis of camels: 12S rRNA gene variation revealed changing pattern of genetic diversity within Echinococcus granulosus sensu lato in the Middle-East and North/ Sub-Saharan Africa. Front Vet Sci 7:618

Deplazes P, Rinaldi L, Alvarez Rojas C, Torgerson P, Harandi M, Romit T, Aantolova D, Schurer J, Lahmar S, Cringoli G (2017) Global distribution of alveolar and cystic echinococcosis. Adv Parasitol 95:315-493

Ebrahimipour M, Sadjjadi SM, Darani HY, Najjari M (2017) Molecular studies on cystic echinococcosis of camel (Camelus dromedarius) and report of Echinococcus ortleppi in Iran. Iran J Parasitol 12:323331

Eckert J, Deplazes P (2004) Biological, epidemiological, and clinical aspects of echinococcosis, a zoonosis of increasing concern. Clin Microbiol Rev 17:107-135

El-Ghareeb WR, Edris AM, Alfifi AE, Ibrahim AM (2017) Prevalence and histopathological studies on hydatidosis among sheep carcasses at Al-Ahsa, Saudi Arabia. AJVS 55:146-153

Fahim F, Al Salamah SM (2007) Cystic echinococcosis in Central Saudi Arabia: a 5-year experience. Turk J Gastroenterol 18:22-27

Farah MO (1987) Infection rates, cyst fertility and larval viability of hydatid diesease in camels, sheep and cattle in Gassim, Saudi Arabia. Vet Res Communi 11:493-495

Fdaladdin YAJ, Alsaggaf AI, Wakid MH (2018) Comparative epidemiological studies on Echinococcosis of local and imported livestock in Al-madina Al-munawwarah in Saudi Arabia. Egypt J Hosp Med 50:108-126

Haroun EM, Omer OH, Mahmoud OM, Draz A (2008) Serological studies on hydatidosis in camels in Saudi Arabia. RJVS 1:71-73
Hayajneh FMF, Althomali AMH, Nasr AT (2014) Prevalence and characterization of hydatidosis in animals slaughtered at $\mathrm{Al}$ Taif abattoir, Kingdom of Saudi Arabia. Open J Anim Sci 04:38-41

Hüttner M, Nakao M, Wassermann T, Siefert L, Boomker JD, Dinkel A, Sako Y, Mackenstedt U, Romig T, Ito A (2008) Genetic characterization and phylogenetic position of Echinococcus felidis (Cestoda: Taeniidae) from the African lion. Int J Parasitol 38:861-868

Ibrahim MM (2010) Study of cystic echinococcosis in slaughtered animals in Al Baha region, Saudi Arabia: interaction between some biotic and abiotic factors. Acta Trop 113:26-33

Kawasmeh Z, Cheema A, Shigidi M (1984) Prevalence of echinococcosis/hydatidosis in stray dogs and slaughtered animals in Al-Hassa region. Symposium on Biological Aspects of Saudi Arabia. Saudi Arabian Biol. Soc., Riyadh 79-80

Kinkar L, Laurimäe T, Simsek S, Balkaya I, Casulli A, Manfredi MT, Ponce-Gordo F, Varcasia A, Lavikainen A, Gonzalez LM, Rehbein SJ, Van Der Giessen J, Sprong H, Saarma U (2016) High-resolution phylogeography of zoonotic tapeworm Echinococcus granulosus sensu stricto genotype G1 with an emphasis on its distribution in Turkey, Italy and Spain. Parasitology 143:1790-1801

Kinkar L, Laurimäe T, Acosta-Jamett G, Andresiuk V, Balkaya I, Casulli A, Gasser RB, Van Der Giessen J, González LM, Haag KL (2018a) Global phylogeography and genetic diversity of the zoonotic tapeworm Echinococcus granulosus sensu stricto genotype G1. Int J Parasitol 48:729-742

Kinkar L, Laurimäe T, Balkaya I, Casulli A, Zait H, Irshadullah M, Sharbatkhori M, Mirhendi H, Rostami-Nejad M, Ponce-Gordo F, Rehbein S, Kia EB, Simsek S, Snabel V, Umhang G, Varvasia A, Saarma U (2018b) Genetic diversity and phylogeography of the elusive, but epidemiologically important Echinococcus granulosus sensu stricto genotype G3. Parasitology 145:1613-1622

Kinkar L, Korhonen PK, Cai H, Gauci CG, Lightowlers MW, Saarma U, Jenkins DJ, Li J, Li J, Young ND, Gasser RB (2019) Long-read sequencing reveals a $4.4 \mathrm{~kb}$ tandem repeat region in the mitogenome of Echinococcus granulosus (sensu stricto) genotype G1. Parasit Vectors 12:238

Konyaev SV, Yanagida T, Nakao M, Ingovatova GM, Shoykhet YN, Bondarev AY, Odnokurtsev VA, Loskutova KS, Lukmanova GI, Dokuchaev NE, Spiridonov S, Alshinecky MV, Sivkova TN, Andreyanov ON, Abramov SA, Krivopalov AV, Karpenko SV, Lopatina NV, Dupal TA, Sako Y, Ito A (2013) Genetic diversity of Echinococcus spp. in Russia. Parasitology 140:1637-1647

Kumar S, Stecher G, Tamura K (2016) MEGA7: molecular evolutionary genetics analysis version 7.0 for bigger datasets. Mol Bio Evol 33: 1870-1874

Laatamna AE, Ebi D, Brahimi K, Bediaf K, Wassermann M, Souttou K, Romig T (2019) Frequency and genetic diversity of Echinococcus granulosus sensu stricto in sheep and cattle from the steppe region of Djelfa, Algeria. Parasitol Res 118:89-96

Lee TH, Pearson MS, Blair D, Dai N, Zhang LH, McManus DP (2002) Complete mitochondrial genomes confirm the distinctiveness of the horse-dog and sheep-dog strain of Echinococcus granulosus. Parasitology 124:97-112

Manske M (2006) GENtle: A Free Multi-purpose Molecular Biology Tool. University of Cologne, Cologne

Metwally DM, Qassim LE, Al-Turaiki IM, Almeer RS, El-Khadragy MF (2018) Gene-based molecular analysis of COX1 in Echinococcus granulosus cysts isolated from naturally infected livestock in Riyadh, Saudi Arabia. PloS One 13:e0195016

Monteiro DU, De Azevedo MI, Weiblen C, Ribeiro TC, Emmanouilidis J, Tonin AA, De Avila BS, de la Rue ML (2016) Echinococcus granulosus sensu stricto, Echinococcus canadensis (G7), and Echinococcus ortleppi in fertile hydatid cysts isolated from cattle in Southern Brazil. Acta Trop 164:41-44

Moro PL, Cavero CA, Tambini M, Briceño Y, Jiménez R, Cabrera L (2008) Identification of risk factors for cystic echinococcosis in a 
peri-urban population of Peru. Trans R Soc Trop Med Hyg 102:7578

Múrias dos Santos A, Cabezas MP, Tavares AI, Xavier R, Branco M (2016) tcsBU: a tool to extend TCS network layout and visualization. Bioinformatics 32:627-628

Nakao M, Okamoto M, Sako Y, Yamasaki H, Nakaya K, Ito A (2002) A phylogenetic hypothesis for the distribution of two genotypes of the pig tapeworm Taenia solium worldwide. Parasitology 124:657-662

Nejad MR, Taghipour N, Nochi Z, Mojarad EN, Mohebbi S, Harandi MF, Zali M (2012) Molecular identification of animal isolates of Echinococcus granulosus from Iran using four mitochondrial genes. J Helminthol 86:485-492

Omer R, Dinkel A, Romig T, Mackenstedt U, Elnahas A, Aradaib I, Ahmed M, Elmalik K, Adam A (2010) A molecular survey of cystic echinococcosis in Sudan. Vet Parasitol 169:340-346

Romig T, Deplazes P, Jenkins D, Giraudoux P, Massolo A, Craig PS, Wassermann M, Takahashi K, de la Rue M (2017) Ecology and life cycle patterns of Echinococcus species. Adv Parasitol 95:213-314
SHAHNAZI M, HEJAZI H, SALEHI M, ANDALIB AR (2011) Molecular characterization of human and animal Echinococcus granulosus isolates in Isfahan, Iran. Acta Tropica 117:47-50

Toulah FH, El Shafi AA, Alsolami MN (2012) Prevalence of hydatidosis among slaughtered animals in Jeddah, Kingdom of Saudi Arabia. J Egypt Soc Parasitol 42:563-572

Toulah FH, El Shafi AA, Alsolami M, Wakid M (2017) Hydatidosis among Imported Animals in Jeddah, Saudi Arabia. J Liver Clin Res 4:1031

WITS. 2015. Available: https://wits.worldbank.org/CountryProfile/en/ Country/SAU/Year/2015/TradeFlow/Import/Partner/by-country/ Product/01-05_Animal [Accessed 20 December 2019]

Yanagida T, Mohammadzadeh T, Kamhawi S, Nakao M, Sadjjadi SM, Hijjawi N, Abdel-Hafez SK, Sako Y, Okamoto M, Ito A (2012) Genetic polymorphisms of Echinococcus granulosus sensu stricto in the Middle East. Parasitol Int 61:599-603

Publisher's note Springer Nature remains neutral with regard to jurisdictional claims in published maps and institutional affiliations. 